\title{
A REVIEW OF THE DEVELOPMENT IN DEFINING CORPORATE SOCIAL RESPONSIBILITY
}

\author{
Le Thi Thanh Xuan ${ }^{(1)}$, Gregory Teal ${ }^{(2)}$ \\ (1) University of Technology, VNU-HCM; (2) University of Western Sydney (Australia) \\ (Manuscript Received on April 04 ${ }^{\text {th }}, 2011$, Manuscript Revised September $21^{\text {st }}$, 2011)
}

\begin{abstract}
Corporate Social Responsibility (hereafter CSR) has recently become the debated concept in both academic and practical controversial as well. The reason used to explain is that there is the lack of clear definition of CSR (Wan-Jan 2006) which could be applied in CSR research. This paper is to review the development in defining the concept "Corporate Social Responsibility" from the decade of 1950 to now. The method to review is to examine definitions as well as studies on defining CSR in order to identify the key themes concerning what CSR is in each decade. The review shows some salience points. First, CSR has a very long development history, but it has been officially documented from 1950. Second, researchers tried to define CSR and involved issues by explaining the scope business should be responsible. Last, among reviewed definitions, Carroll's one is more comprehensive than others and widely-used in research.
\end{abstract}

Key words: Corporate Social Responsibility. Stakeholder, social responsibility

CSR has now become an embedded concept in organizational life. It leads to the increasing number of studies on CSR in either academic or practical research. However, one of limitations of these studies is that they have been based on different CSR definitions and frameworks (Balasubramanian, Kimber et al. 2005). The reason used to explain is that there is the lack of clear definition of CSR (Moir 2001; Balasubramanian, Kimber et al. 2005; Wan-Jan 2006; Ahlstrom and Egels-Zanden 2008; Dahlsrud 2008) which could be applied in CSR research. This paper is to review the development in defining the concept "Corporate Social Responsibility" from the decade of 1950 s to now in order to find out the most comprehensive definition which is widely-accepted and can be used as a framework for CSR research.

\section{AN OVERVIEW ABOUT THE DEVELOPMENT IN DEFINING CSR}

The concept of CSR has attracted researchers' attention for a very long time. However, after 1950s, the literature of CSR is rapidly enriched by many studies in theory and practice as well (Carroll 1999). This paper provides an overview about the development in defining CSR as well as the involved themes in these definitions. This section uses Carroll's (1999) taxonomy to approach the definitions of
CSR in which he categorized these definitions by decade. Therefore, there are six important periods after 1950: 1950s, 1960s, 1970s, 1980s, 1990s and 2000s. Table 1 summarizes the involved issues and definitions acquired in studies over decades. The following presents key characteristics in CSR definitions in each decade.

\section{Before 1950}

Before 1950s, no formal definitions were reached. The key themes mentioned in thisperiod studies were post-game philanthropy, pre-game legal constraint and in-game moral conduct (Windsor 2001). The main points mentioned were philanthropy and profitseeking. However, the concept of "philanthropy" was understood only after business competition, without legal control or moral forces. The researchers and the studies in this period focused on the importance of profit maximization as the only duty of a business. The other point in studies on CSR also stated the crucial role of government in "mixed economy" which consisted of more and less regulated industries.

\section{$\underline{1950-1960}$}

The foremost study in this period is that of Bowen in 1953 (Carroll 1999). In his cardinal book Social Responsibilities of the Businessman, Bowen provided the first 
definition of social responsibilities which was applied for businessmen.

"It refers to the obligations of businessmen to pursue those policies, to make those decisions, or to follow those lines of action which are desirable in terms of the objectives and values of our society" (Bowen 1953, p.6, cited in Carroll 1999)

According to Bowen (1953, cited in Carroll 1999), social responsibility is no panacea and it related to somewhat wider than profit-making and "values of our society". To state this first definition, Bowen based on the result of a survey conducted in 1946, in which over $93.5 \%$ participants agreed that businessmen are responsible for somewhat wider than profit statement. With the first documented definition, Bowen was called as the 'Father of CSR' (Carroll 1999; Windsor 2001).

\section{0-1970}

The development of defining CSR in this decade was impressively acquired. Researchers tried to formulate the meaning of CSR are comprised of Davis (1960), Frederick (1960), McGuire (1963), Davis and Blomstrom (1966), Davis (1967), Walton (1967). They successfully expressed what CSR is. Each scholar had his/her own perspective about CSR and mentioned it with different relating issues. The key themes in those definitions are profitability in the long-run, legalism, voluntariness or something beyond these which they called "expectations of the public". It is also needed to note that the term "businessmen" being used till the middle of this decade.

\section{$\underline{1970-1980}$}

The growth of CSR definition was so rapid in this time with many researchers' participations. Although there were not many CSR definitions expressed and the expressed ones are not clear, such as that of Heald (1970); the themes in previous decades, e.g. profitability, voluntariness, legalisms, social problems, were reconfirmed. The issues relating to stakeholders were mentioned as a crucial point in the study of Johnson (1971). Especially, the construction of CSR in the publication of Committee for Economic Development (1971) was responding to social movements in term of environment, worker safety, consumers and employees. In addition, Fitch (1976) broadened CSR to solving social problems that corporation wholly or partly caused.

Importantly, Carroll (1979) offered a comprehensive definition of CSR which is included 4 categories of responsibilities, namely economic, legal, ethical and discretionary responsibilities. Carroll also emphasized the nature of business is profitmaking.

1980-1990

There were more studies on defining CSR than the previous decades; however fewer definitions were formulated (Carroll 1999). Most of research in this decade was not lead to definitions, but they mentioned related issues in social responsibility. In this period, the new concepts were proposed, such as corporate social responsiveness, corporate social performance, public policy, and business ethics. Especially, the proposed themes of CSR were extended beyond what business has to satisfy its shareholders to different social groups who are called stakeholders. Also in this decade, the term "environment" was firstly mentioned in studies. Generally, the main involved CSR issues are voluntariness, legalism, and stakeholder.

1990-2000

The last decade of the $20^{\text {th }}$ century had not got any marked significance in defining CSR (Carroll 1999). The CSR definitions did not have any new points as well as the involved issues of CSR. No new definitions were added to the literature. In this period, CSR was understood as corporate social performance and aligned with corporate social responsiveness. The key themes studied were corporate social performance, stakeholder theory, business ethics theory, and corporate citizenship.

2000 - Now

There are several CSR definitions documented after 2000. Most of definitions and relating issues are similar to those in previous decades. However, the emerging concern in this decade is environment. Definitions which were extended to this issue were initially claimed by Foran and Commission of the European Communities (2001, cited in Dahlsrud 2008). Overall, the concerned issues are also voluntariness, stakeholders, social, environment, and profit-making. Each definition was depended on the authors' 
perception as to CSR; therefore it did not contain all aspects.

In general, among themes in reviewed definitions, stakeholder is an important emerging theme which has been changing the way to perceive CSR. Stakeholder is defined as someone can affect or be affected by firm's operation (Freeman 1984). From this idea, the key issue is whether stakeholder satisfaction is motivation for business to be responsible (Moir 2001). If so, which groups of stakeholders should the board of management pays attention to? In fact, employees always ask for good salary, better working conditions and so on; while customers require quality and reasonable price. The firm's activities must be approved by these stakeholders. Therefore, the question to answer is whether business should pay attention to who has power and urgency or whether it has to balance stakeholders' interest in directing the activities of firm.

\section{CARROLL'S}

CSR

\section{CONCEPTUALIZATION}

In his 1979-study, Carroll (1979) integrated all relevant aspects of CSR means and articulated a definition to cover the whole responsibilities that business has to respond in order to satisfy stakeholders' expectations. In retrospect, CSR involves the expectations that society has of business. Therefore, CSR should include the economic, legal, ethical and discretionary responsibilities.

a. Economic responsibilities

Friedman (1970) asserted that business has only one responsibility which is to increase its profits. Friedman (1970) analyzed duties that a business needs to exercise. From perspectives of different stakeholders, e.g. shareholders, customers, employees, it is clearly shown that all a business has to do is maximizing profits. Hence, according to Carroll (1979; 1991), in order to exist in a competitive market, business, which is defined as 'the basic economic unit', is required to be profitable. Therefore, it is easy to recognize that profit-making is the most crucial obligation that a business has to satisfy its owners in maximizing earning per share, maintaining a strong competition position and a high level of operating efficiency.

This range of responsibilities is the basic of a business and the underpinning of all the other responsibilities.

\section{b. Legal responsibilities}

Although Dalton and Cosier (1982) did not give any definition for the concept of CSR, they claimed that legal responsibilities as well as ones beyond the law belong in business's accountability. These types of responsibilities demand that business is expected to conduct its operation under the laws and regulations. In the other words, economic missions should be fulfilled within the framework of the law (Carroll 1979; Carroll 1991). These responsibilities are as fundamental as the economic responsibilities are (Carroll 1999) and determined by the public or government who is representative for the public (Dalton and Cosier 1982). This range of responsibilities is applied not only to companies but also to individuals while they are acting as members of those companies.

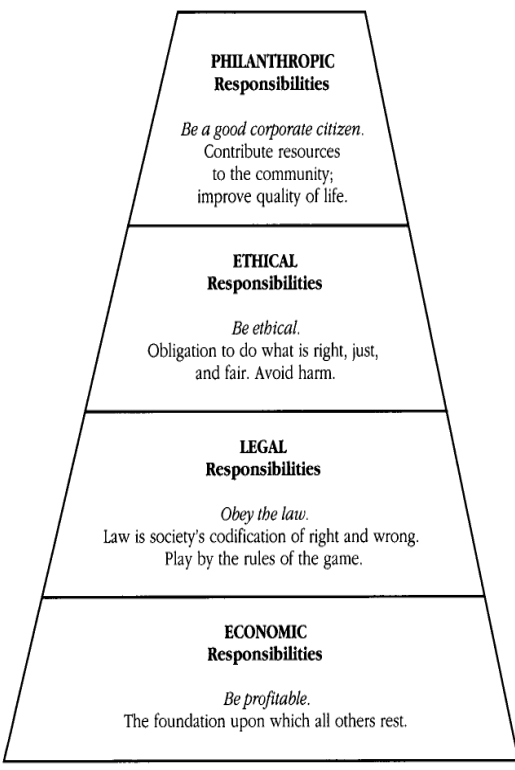

Figure: The pyramid of Corporate Social Responsibility (Carroll 1979)

\section{c. Ethical responsibilities}

These duties are also related to public's expectations and explained in many studies, such as Frederick 1960, Backman 1975 (cited in Carroll's (1999) study). In fact, there are many issues are still debated by the public as to whether they are ethical or legal (Carroll 1979). Hence, ethical responsibilities are derived from 'newly emerging values and norms' and are not documented in laws or requirements (Carroll 1991; Carroll 1998). Because of not codifying 
into law, these obligations are not compulsory but they are stakeholders' concerns and may move to the legal responsibility category at the future time. However, an ethical responsibility is more difficult for business to anticipate and follow.

\section{d. Philanthropic responsibilities}

The common thinking as to what CSR means is the willingness that business offers to the society, especially to the poor, the victims of disasters. This idea also was affirmed in some studies, e.g. Walton (1967), Manne and Wallich (1972), Eilbert and Parket (1973); which are cited in Carroll (1999) or McWilliam and Siegel (2001) which is cited in Dahlsrud (2008). Nonetheless, CSR is not simply restricted to philanthropy. These philanthropic duties are only one of business's responsibilities. This category of responsibility is not mandatory, not framed into law, not considered as ethical activities; but it is what business does to be a good citizen (Carroll 1979; Carroll 1991). Carroll (1991) also pointed out that business are not seen as unethical whether it offers this willingness to the society. However, in fact, companies carry out these obligations very commonly.

\section{THE COMPREHENSIVENESS OF} CARROLL'S DEFINITION

The involved issues mentioned in CSR definitions are separated and increasingly developed. Based on the overview about the development in defining CSR, it can be concluded that, Carroll's CSR definition is the most widely-accepted and used in empirical studies. Carroll (1979) documented and integrated the existing aspects into a definition which completely explains what CSR is.

'The social responsibility of business encompasses the economic, legal, ethical, and discretionary expectations that society has of organizations at a given point in time.' (Carroll 1979, p. 500)

The approach to classify CSR definitions categorized by Banerjee (2007) includes some key themes. First, in-the-short-run obligations are identified to reflect what a firm should formulate in its policies and actions. Second, CSR often exceeds mandatory legal requirements, such as 'providing free day care for its employees'. Third, voluntary activities are mentioned as CSR. And, last, concern of 'society' and 'social interests' form the term 'stakeholder' and narrow the responsibilities that a company has to respond. By this category, Banerjee (2007) asserts that Carroll's definition reflects the nature and type of responsibilities of business.

Another of CSR definitions also affirms the comprehensiveness of Carroll's definition. First, CSR can be explained with two functions, namely: socio-economic and sociohuman obligations. Second, defining CSR is from the points of view of both legitimacy theory and stakeholder theory, which directly impact business decisions (Stratling 2007, p. 66). Last, the way to define CSR is based on viewpoint of social issue management and stakeholder management (Gao 2009). Carroll's definition belongs to the first view, but it also can cover the others. From the view of legitimacy theory and stakeholder theory, this definition addresses the legal category which satisfies its various stakeholders. It also helps to answer all aspects of social issues management and stakeholder management of the last view.

The review of literature shows that, Carroll's CSR definition is more comprehensive than the others as it can integrate all existing aspects and can be explained by all approaches of defining CSR.

\section{CONCLUSION}

This paper reviews CSR along with its history in development. There are some significant points which should be noted. First, CSR has a very long development history, but it has been officially documented from 1950s. Second, researchers tried to define CSR and involved issues by explaining the scope business should be responsible. Last, among reviewed definitions, Carroll's one is more comprehensive than others and widely-used in research.

Although the controversial as to how to define CSR is continuing; up to now, Carroll's definition is the most-widely accepted and used in academic and practical studies as well. It can satisfy different viewpoints as it can integrate all existing aspects and can be explained by all existing approaches of defining CSR. Nevertheless, this definition has remained some limitations in explaining and applying in research. One of these limitations is that this 
definition cannot help practitioners to clearly identify each category of responsibilities because the boundaries between four types are not clear (Griseri 2010). For example, it is difficult for businesses to deal with the ethical requirements which are the interplay with legal ones, but are not clear and well-defined. The other limitation of this definition relates to the conflicts between stakeholders. Each stakeholder is expecting different benefits from business and these benefits sometimes contradict each other. Business then must balance these benefits and expectations. However, Carroll's definition cannot help to solve such benefits and expectations. Therefore, further research on defining CSR should focus to address the above limitations in order to fill the gap between theory and practice.

\title{
SỰ PHÁT TRIỂN TRONG CÁC ĐỊNH NGHĨA KHÁI NIỆM TRÁCH NHIỆM XÃ HộI
}

\author{
Lê Thị Thanh Xuân ${ }^{(1)}$, Gregory Teal ${ }^{(2)}$ \\ (1) Trường Đại học Bách khoa, ĐHQG-HCM \\ (2) University of Western Sydney (Australia)
}

TÓM TĂT: Nhũng năm gần đây, trách nhiệm xã hội (TNXH) là một khái niệm được tranh luận nhiều hơn, không chỉ ở các nghiên cúu học thuật mà còn ở việc triển khai thực hiện. Lý do chủ yếu giải thích cho sụ tranh luận này là thiếu một định nghĩa rõ ràng và đầy đủ về TNXH (Wan-Jan 2006). Muc tiêu của bài báo này là hệ thống lại sụ phát triển trong viẹc định nghĩa về TNXH tù thập niên 1950 đến nay. Kết quả ghi nhận một số yếu tố quan trọng. Thứ nhất, TNXH được phát triển một thời gian dài, tuy nhiên các định nghĩa được ghi nhận và định nghĩa đầu tiên được phát biểu chính thức ở thập kỷ 1950. Thứ hai, các nhà nghiên cúu định nghĩa TNXH và xác định các vấn đề liên quan đến TNXH thông qua việc xác định và giải thích phạm vi trách nhiệm của doanh nghiệp. Thư ba, trong số các định nghĩa, định nghĩa về TNXH của Carroll (1979) được đánh giá cao về múc độ bao quát và được nhiều nghiên cứu sử dụng làm mô hình nghiên cứu. Ngoài ra, các giới hạn trong định nghĩa này cũng được xác định để các nghiên cứu về sau định huớng giải quyêtt.

Tù khóa: trách nhiệm xã hội, đối tương hũu quan.

\section{REFERENCES}

[1]. Ahlstrom, J \& Egels-Zanden, N 2008, 'The processes of defining corporate responsibility: a study of Swedish garment retailers' responsibility', Business Strategy and the Environment, vol. 17, pp. 230-244.

[2]. Balasubramanian, NK, Kimber, D \& Siemensma, F 2005, 'Emerging opportunities or traditions reinforced? An analysis of the attitudes towards CSR and trends of thinking about CSR, in India', The Journal of Corporate Citizenship, vol. 17, pp. 79-92.

[3]. Banerjee, B, Subhabrata 2007, Corporate social responsibility: the good, the bad and the ugly, Cheltenham: Edward Elgar Publishing Limited.
[4]. Carroll, AB 1979, 'A three dimensional conceptual model for corporate peformance', Academy of Management Review, vol. 4, no. 4, pp. 497-505.

[5]. Carroll, AB 1991, 'The pyramid of corporate social responsibility: toward the moral management of organizational stakeholders', Business Horizons, vol. 34, pp. 39-48.

[6]. Carroll, AB 1998, 'The four faces of corporate citizenship', Business and Society Review, vol. 100/101, pp. 1-7.

[7]. Carroll, AB 1999, 'Corporate social responsibility: evolution of a definitional construct', Business \& Society, vol. 38, no. 3, pp. 268-295.

[8]. Dahlsrud, A 2008, 'How corporate social responsibility is defined: an analysis of 37 
definitions', Corporate Social Responsibility and Environmental Management, vol. 15, no. 1-13.

[9]. Dalton, DR \& Cosier, RA 1982, 'The four faces of social responsibility', Business Horizons, vol. 25, no. 3, pp. 19-27.

[10]. Freeman, ER 1984, Strategic management: a stakeholder approach, Pitman, Boston, MA.

[11]. Friedman, M 1970, 'The social responsibility of business is to increase its profits", New York Times Magazine, vol. 33, pp. 122-126.

[12]. Gao, Y 2009, 'Corporate social performance in China: evidence from China', Journal of Business Ethics, vol. 89, pp. 23-35.
[13]. Griseri, P 2010, Business ethics and corporate social responsibility, South-Western Cengage Learning, [S.1.]

[14]. Moir, L 2001, 'What do we mean by corporate social responsibility?', Corporate Governance, vol. 1, no. 2, pp. 16-22.

[15]. Stratling, R 2007, 'The legitimacy of corporate social responsibility', Corporate Ownership and Control, vol. 4, no. 4, pp. 6573.

[16]. Wan-Jan, WS 2006, 'Defining corporate social responsibility', Journal of Public Affairs, vol. 6, pp. 176-184.

[17]. Windsor, D 2001, 'The future of corporate social responsibility', The International Journal of Organizational Analysis, vol. 9, no. 3, pp. 225-256. 
TẠP CHÍ PHÁT TRIỂN KH\&CN, TẬP 14, SỐ Q2 - 2011

Table 1: THE DEVELOPMENT IN DEFINING CSR

\begin{tabular}{|c|c|c|c|c|}
\hline Period & $\begin{array}{r}\text { Involved issues } \\
\end{array}$ & Definitions & Cited from & Authors \& Year \\
\hline $\begin{array}{l}\text { Progressive Era } \\
\text { (Before 1950) }\end{array}$ & $\begin{array}{l}\text { - Post-game philanthropy } \\
\text { - Pre-game legal constrain } \\
\text { - In-game moral conduct }\end{array}$ & None & & (Windsor 2001) \\
\hline $\begin{array}{l}\text { Modern Era of CSR: } \\
\text { the } 1950 \text { s }\end{array}$ & Somewhat wider than profit-making & $\begin{array}{l}\text { 'It refers to the obligations of businessmen to pursue those policies, to make those decisions, or to } \\
\text { follow those lines of action which are desirable in term of the objectives and values of our society' }\end{array}$ & Bowen (1953) & (Carroll 1999) \\
\hline $\begin{array}{l}\text { CSR literature } \\
\text { expands: the } 1960 \text { s }\end{array}$ & $\begin{array}{l}\text { - Long-run economic } \\
\text {-Paying back for socially responsible outlook } \\
\text {-economic activities } \\
\text {-expectations of the public } \\
\text {-economic and legal obligations } \\
\text {-responsibilities beyond these obligations } \\
\text {-economic and technical interest } \\
\text { - beyond these interest } \\
\text {-voluntary of the firm }\end{array}$ & $\begin{array}{l}\text { 'businessmen's decisions and actions taken for reasons at least partially beyond the firm's direct } \\
\text { economic and technical interest' } \\
\text { 'Social responsibilities mean that businessmen should oversee the operation of an economic } \\
\text { system that fulfills the expectations of the public. And this means in turn that the economy's } \\
\text { means of production should be employed in such a way that production and distribution should } \\
\text { enhance total socio-economic welfare.' } \\
\text { 'The idea of social responsibilities supposes that the corporation has not only economic and legal } \\
\text { obligations but also certain responsibilities to society which extend beyond these obligations' } \\
\text { 'SR refers to a person's obligation to consider the effects of his decisions and actions on the whole } \\
\text { social system. Businessmen apply SR when they consider the needs and interest of others who } \\
\text { may be affected by business actions. In so doing, they look beyond their firm's narrow economic } \\
\text { and technical interests.' } \\
\text { 'The new concept of SR recognizes the intimacy of the relationship between the corporation and } \\
\text { society and realizes that such relationship much be kept in mind by top managers as the } \\
\text { corporation and the related groups pursue their perspective goals' }\end{array}$ & $\begin{array}{l}\text { Davis and } \\
\text { Blomstrom (1966) } \\
\text { Walton (1967) }\end{array}$ & (Carroll 1999) \\
\hline $\begin{array}{l}\text { Definitions of CSR } \\
\text { proliferate: the } 1970 \text { s }\end{array}$ & $\begin{array}{l}\text {-the same ideas with those in 1960s and earlier } \\
\text {-profits for stockholders } \\
\text {-responsibilities with employees, suppliers, } \\
\text { dealers, local communities, and the nation } \\
\text {-economic function } \\
\text {-awareness of changing social values and } \\
\text { priorities } \\
\text {-improving social environment }\end{array}$ & $\begin{array}{l}\text { None } \\
\text { None } \\
\begin{array}{l}\text { A three concentric circles definition of SR: the inner circle, the intermediate circle and the outer } \\
\text { circle }\end{array}\end{array}$ & $\begin{array}{l}\text { Committee for } \\
\text { Economic } \\
\text { Development (1971) }\end{array}$ & (Carroll 1999) \\
\hline
\end{tabular}

Trang 112 
TẠP CHÍ PHÁT TRIỂN KH\&CN, TẬP 14, SỐ Q2 - 2011

\begin{tabular}{|c|c|c|c|c|}
\hline & $\begin{array}{l}\text { economic function and social interests } \\
\text {-economic returns } \\
\text {-voluntary } \\
\text {-issues beyond the economic, technical and } \\
\text { legal requirements } \\
\text {-not harming the social problem } \\
\text {-voluntary to help solve those problems } \\
\text {-social needs and goals beyond the economic } \\
\text {-economic performance } \\
\text {-improving quality of life } \\
\text { Empirical studies on CSR } \\
\text {-social problems } \\
\text { Analysis annual report including social } \\
\text { involvement categories } \\
\text {-Make profit; Obey the law; Ethical and } \\
\text { Discretionary }\end{array}$ & $\begin{array}{l}\text { None } \\
\text { '... a condition in which the corporation is at least in some measure a free agent. To the extent that } \\
\text { any of the foregoing social objectives are imposed on the corporation by law, the corporation } \\
\text { exercises no responsibility when it implements them' } \\
\text { 'It is the firm's obligation to evaluate in its decision-making process the effect of its decisions on } \\
\text { the external social system in a manner that will accomplish social benefits along with the } \\
\text { traditional economic gains which the firm seeks' } \\
\text { None } \\
\text { None } \\
\text { 'SR usually refers to the objectives or motives that should be given weight by business in addition } \\
\text { to those dealing with economic performance (e.g. profit)' } \\
\text { None } \\
\text { 'CSR is defined as the serious attempt to solve social problems caused wholly or in part by the } \\
\text { corporation' } \\
\text { None }\end{array}$ & $\begin{array}{l}\text { Davis (1973) } \\
\text { Eilbert and Parket } \\
\text { (1973) } \\
\text { Eells and Walton } \\
\text { (1974) } \\
\text { Backman (1975) } \\
\text { Bowman and Haire } \\
\text { (1975); Holmes } \\
\text { (1976) } \\
\text { Fitch (1976) } \\
\text { Abbott and Monsen } \\
\text { (1979) } \\
\text { Carroll (1979) }\end{array}$ & \\
\hline $\begin{array}{l}\text { 1980s: fewer } \\
\text { definitions, more } \\
\text { research and } \\
\text { alternative themes }\end{array}$ & $\begin{array}{l}\text {-voluntary } \\
\text {-extending beyond the traditional duty to } \\
\text { shareholders to other groups such as customers, } \\
\text { employees, suppliers, neighboring communities }\end{array}$ & $\begin{array}{l}\text { 'CSR is the notion that corporations have an obligation to constituent groups in society other than } \\
\text { stockholders and beyond that prescribed by law and union contract' }\end{array}$ & Jones (1980) & (Carroll 1999) \\
\hline
\end{tabular}

Trang 113 
TẠP CHÍ PHÁT TRIỂN KH\&CN, TẬP 14, SỐ Q2 - 2011

\begin{tabular}{|c|c|c|c|c|}
\hline & $\begin{array}{l}\text {-Legal-responsible } \\
\text {-social responsibility; } \\
\text {-social responsiveness } \\
\text {-social environment } \\
\text {-convert SR into business opportunities } \\
\text { Empirical study about social performance and } \\
\text { financial performance } \\
\text { Empirical study about CSR and profitability } \\
\text { Framework of principles, processes, and } \\
\text { policies } \\
\text {-stakeholders }\end{array}$ & $\begin{array}{l}\text { None } \\
\text { No new or unique definition of CSR } \\
\text { None } \\
\text { None } \\
\text { None } \\
\text { none } \\
\text { CSR relates primarily to achieving outcomes from organizational decisions concerning specific } \\
\text { issues or problems which have beneficial rather than adverse effects on pertinent corporate } \\
\text { stakeholders. }\end{array}$ & $\begin{array}{l}\text { Dalton and Cosier } \\
\text { (1982) } \\
\text { Strand (1983) } \\
\text { Drucker (1984) } \\
\begin{array}{l}\text { Cochran and Wood } \\
\text { (1984) }\end{array} \\
\text { Aupperle et al (1985) } \\
\text { Wartick and Cochran } \\
\text { (1985) } \\
\text { Epstein (1987) }\end{array}$ & \\
\hline $\begin{array}{l}\text { 1990s: Alternative } \\
\text { themes in CSR }\end{array}$ & $\begin{array}{l}\text {-mainly basing on CSR model of Carroll } \\
\text { (1979) and Wartick \& Cochran (1985) } \\
\text {-more explicit outcomes/performance } \\
\text {-4 components of CSR; building a pyramid; } \\
\text { economic is the foundation and stakeholders } \\
\text { The most attention in CSR: CSP; business } \\
\text { ethics and stakeholder theory }\end{array}$ & None & Carroll (1994) & (Carroll 1999) \\
\hline $2000 \mathrm{~s}$ & $\begin{array}{l}\text {-voluntariness; stakeholders; social; } \\
\text { environment and economic } \\
\text { Social concern }\end{array}$ & $\begin{array}{l}\text { A concept whereby companies integrate social and environmental concerns in their business } \\
\text { operations and in their interaction with their stakeholders on a voluntary basis. } \\
\text { Corporate social responsibility or corporate citizenship can most simply be defined as a set of } \\
\text { management practices that ensure the company minimizes the negative impacts of its operations }\end{array}$ & $\begin{array}{l}\text { Commission of the } \\
\text { European } \\
\text { Communities (2001) } \\
\text { Pinney (2001) }\end{array}$ & (Dahlsrud 2008) \\
\hline
\end{tabular}

Trang 114 
TẠP CHÍ PHÁT TRIỂN KH\&CN, TẬP 14, SỐ Q2 - 2011

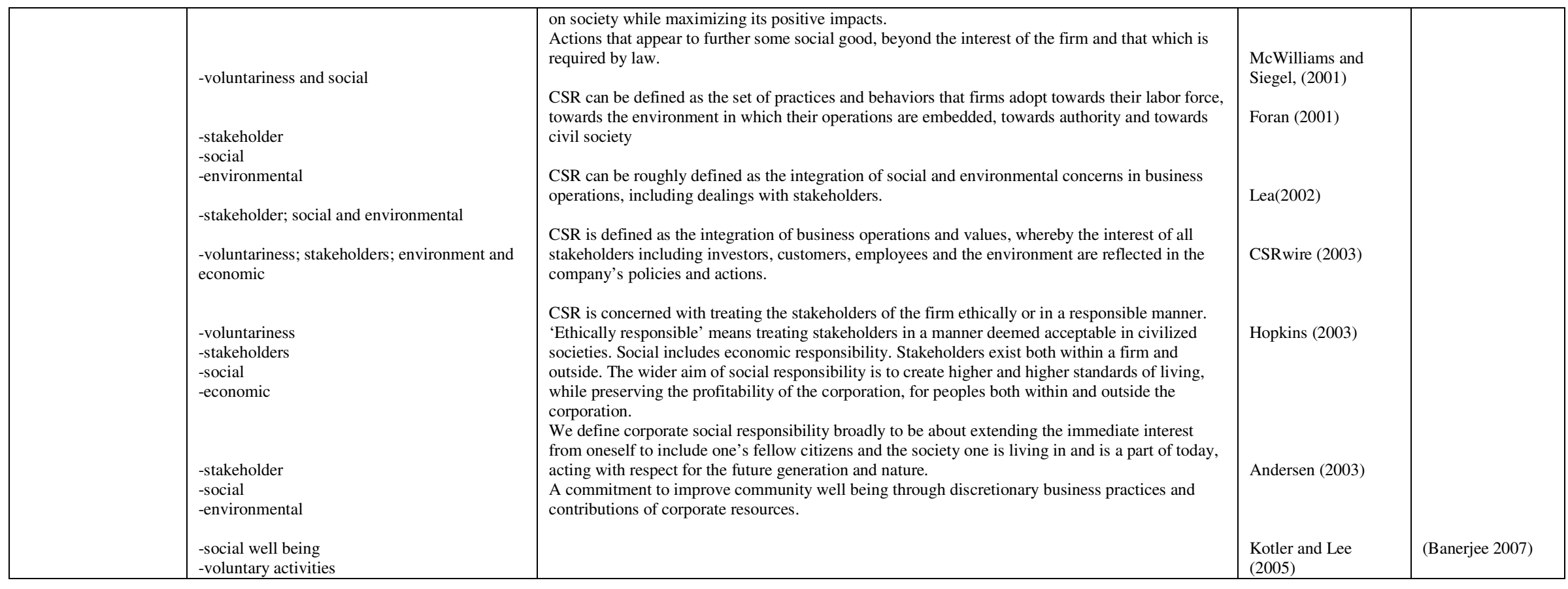

